This is an Accepted Manuscript of an article published by Elsevier in Marine Environmental Research, available online:

https://www.sciencedirect.com/science/article/abs/pii/S0141113617306220

\title{
Diel and seasonal changes in the spatial behaviour of a soft- sediment fish (Solea senegalensis) inside a marine reserve
}

Miguel Gandra $\mathrm{a}^{\mathrm{a}}$, Karim Erzini ${ }^{\mathrm{b}}$, David Abecasis ${ }^{\mathrm{b}}$

${ }^{a}$ Faculty of Sciences and Technology, University of the Algarve, Campus de Gambelas, 8005-139 Faro, Portugal

${ }^{\mathrm{b}}$ Centre of Marine Sciences (CCMAR), University of the Algarve, Campus de Gambelas, 8005-139 Faro, Portugal

*Corresponding author: m3gandra@gmail.com 


\begin{abstract}
The protection provided by marine reserves directly depends on the short and long-term movement patterns of local organisms. Although there has been an increase in research assessing the behavioural patterns of fishes in reef-based habitats, there is still a paucity of studies addressing the benefits of marine protected areas (MPAs) for soft sediment species. Here, we investigated both diel and seasonal shifts in spatial behaviour of the Senegalese sole, Solea senegalensis, within a recently-established marine reserve using long-term passive acoustic telemetry. Results showed variable levels of site attachment, with nearly half of the fish $(n=8)$ disappearing from the monitored area within 30 days, and the remaining $(n=9)$ being detected for periods up to 207 days and spending $95 \%$ of their time within an average area of $0.88 \pm 0.46 \mathrm{~km}^{2}$. Although detection frequency was higher during daytime periods, the larger home range areas and greater movement observed during nighttime periods are consistent with a nocturnal activity regime, which might increase the vulnerability of $S$. senegalensis to illegal fishing. Additionally, patterns observed during the spawning season suggest the existence of shifts in habitat use linked with reproductive activity, opening the door to further research on soles' fine-scale interaction dynamics. Overall, this study provides novel insights into the ecology of a flatfish species and suggests that small no-take areas encompassing suitable softsediment habitats can offer adequate protection to at least part of the Senegalese sole population.
\end{abstract}

Keywords: Senegalese sole; Flatfish; Diel activity; Spawning; Home range; Site fidelity; Acoustic telemetry; Marine protected areas. 


\section{Introduction}

Over the last decades, marine protected areas (MPAs) have been increasingly used as a tool for conservation and fisheries management. Throughout the world, MPAs have been acknowledged to yield benefits such as increased species richness, augmented productivity, higher fish biomass and larger fish sizes (Roberts et al. 2001, Horta e Costa et al. 2013, Russ et al. 2015). Moreover, these effects may contribute to the replenishment of exploited populations outside MPA boundaries through the passive dispersion of larvae and the net export of juvenile and adult biomass, a mechanism commonly known as "spillover" (Gell \& Roberts 2003, Vandeperre et al. 2011). Together, these factors can help counterbalance catch losses, while simultaneously assuring the long-term sustainability of fish assemblages.

These dynamics are, however, largely dependent of the capacity of the MPA to encompass movements of local populations and to protect essential habitats, such as breeding or nursery grounds (Abecasis et al. 2015). Indeed, many species are known to undertake reproductive migrations outside their habitual home range and form spawning aggregations. Being highly predictable in space and time, these aggregations are intrinsically more vulnerable to fishing and overexploitation, and thus can rapidly decline or even completely disappear without adequate management schemes (Sadovy \& Domeier 2005, Grüss et al. 2014). In addition to extended migrations, most fish also undertake small scale movements on a daily basis. Factors such as food availability or predator avoidance might drive both tidal or diel habitat shifts on smaller spatial scales. Despite the inherent difficulty of accounting for both temporal and spatial unpredictability in species movements, this information is of vital importance not only to evaluate the suitability of MPAs in protecting particular species but also to provide guidelines for future management planning.

Within the Portuguese coast, the Senegalese sole, Solea senegalensis (Kaup 1858), is one of the most important commercial species, targeted by small-scale fisheries and farmed in extensive aquacultures. This flatfish of the Soleidae family, occurs throughout the Eastern Central Atlantic, as well as in the western Mediterranean (Quéro et al. 1986). Adults are usually found on sandy or muddy bottoms (Abecasis et al. 2014a) down to $100 \mathrm{~m}$, while juveniles typically inhabit shallower estuarine habitats (Vasconcelos et al. 2010). Despite the species' importance, knowledge about its spatial ecology and behaviour in the wild remains relatively scarce. Indeed, most studies to date have focused on its juvenile phase (e.g. Cabral 2000, Vinagre et al. 2006a, Vinagre et al. 2006b) or physiological aspects for aquaculture purposes (e.g. Anguis \& Canavate 2005, Firmino et al. 2017). Only more recently, Abecasis et al. 
(2014a) investigated the movements of mature Senegalese sole using experimental fishing trials and long-term passive acoustic telemetry. Nonetheless, the latter study did not address temporal patterns in Senegalese sole habitat use and spatial behaviour.

The objective of this study was therefore to investigate the existence of spatio-temporal shifts in habitat use of adult Senegalese soles within the context of a recently established MPA. Specifically, our aims were: (1) to compare space usage between the no-take zone and the partially protected area, (2) to search for potential aggregation events within the monitored areas, and (3) to identify behavioural changes associated with day-night and reproductiveresting cycles.

\section{Materials and Methods}

\subsection{Study site}

This study took place in the Professor Luiz Saldanha Marine Park (LSMP), a $53 \mathrm{~km}^{2}$ marine park that stretches over $38 \mathrm{~km}$ of Portuguese coastline (Fig. 1A). The main habitats in the park include nearshore shallow rocky reefs and shallow rocky outcrops, with sandy bottoms covering the majority of the park from shallow to deeper areas, where muddy bottoms dominate (Fig. 1C; Henriques et al. 2015). The management plan, approved and implemented gradually starting in mid-2005, defines 3 different protection levels (Fig. 1B): one no-take area (NT; 4.2 $\mathrm{km}^{2}$ in area); four partially protected areas (PPAs; totaling $21 \mathrm{~km}^{2}$ ); and two buffer areas (BAs; totaling $28 \mathrm{~km}^{2}$ ). The NT is a no-take, no-access area (except for research, monitoring and education purposes) and is therefore considered a marine reserve. Commercial fishing vessels require a permit to operate within the LSMP and are limited to a maximum length of $7 \mathrm{~m}$. In the PPAs commercial fishermen are only allowed to use octopus traps and jigs whereas in the BAs all traditional small-scale fishing gears are allowed. Recreational angling is also allowed but spearfishing is banned in the entire LSMP. The different MPA zones were created based on the scarce data available - mainly regarding reef fish visual census - and with the objective of protecting coastal habitats and ensuring the livelihood of local fishermen. 


\subsection{Fish tagging}

Seventeen Senegalese soles were captured during the experimental trammel net fishing campaign of October 2010: eleven fish were captured inside the no-take area and six were captured inside the partially protected area located east of the no-take area (Fig. 1B). The total length of all individuals was measured and matched to the findings of Teixeira \& Cabral (2010), so as to infer that the seventeen Senegalese soles were mature individuals between 3 and 8 years old. All individuals were tagged with an acoustic transmitter (Vemco V9-2L with an expected lifetime of 282 days) that was attached externally on the eyed side underneath the dorsal fin (median region). The transmitters were previously glued to a smooth rubber plate, with two nylon sutures $1 \mathrm{~cm}$ apart. These sutures were passed through the muscle underneath the pterigiophores of the dorsal fin and another rubber plate was placed on the opposite side (blind side) where threads were knotted. This tagging procedure was carried out without anaesthesia and was similar to that used by Bégout Anras et al. (2003) for Solea solea. After the attachment of the acoustic transmitter, fish were released at the site of capture.

\subsection{Acoustic Monitoring}

The presence of the tagged Senegalese sole was monitored with 18 acoustic receivers (Vemco VR2 and VR2W) that were moored in an array that comprised two lines of 9 receivers each. These lines were deployed parallel to the coastline and covered the no-take area and one neighbouring partial protection zone (Figure 1B). The inner line covered depths from 8 to 14 $\mathrm{m}$ (receivers moored at about $1 \mathrm{~m}$ from the bottom), and the outer line cover depths from 17 to $21 \mathrm{~m}$ (receivers suspended at approximately $5 \mathrm{~m}$ from the bottom). Monitoring activities took place between October 2010 and January 2012, outlasting the expected lifetime of the acoustic tags. Six receivers from the outer line and two receivers from the inner line were lost following the first data download that took place on 17 November 2010, likely due to illegal fishing. The loss of these receivers was discovered during the second data download that took place in April 2011, leading to the deployment of 4 new receivers in slightly different locations in May 2011 (Figure 1b). Two different tag performance tests were carried out during a 25-day period before the release of tagged animals. The first one was performed by lowering an acoustic transmitter (similar to the ones used to tag Senegalese sole; V9-2L) from a boat at known distances from the receivers. After placing the tag at each location for 60 minutes, we retrieved the data from the loggers and estimated the percentage of acoustic signals successfully detected. This test showed detection ranges of approximately $300 \mathrm{~m}$ ( $72 \%$ of detections) for both inner and outer 
line receivers. The second test was carried out by deploying a tag close to the sea bottom (soft substrate at a depth of approximately $10 \mathrm{~m}$ ) for 22 consecutive days, at $300 \mathrm{~m}$ from the nearest receiver. Although strong winds and high precipitation decreased the detection rate, no significant differences were found on a diel basis (day vs night, chi-square=1.474; $\mathrm{p}=0.22$ ).

\subsection{Data analysis}

Acoustic detections of tagged Senegalese soles were managed using the VUE database (Vemco Ltd., Halifax, Nova Scotia) and all of the analyses were conducted in R (R Core Team 2017).

In order to prevent false-positive errors, detections from a single transmitter ID occurring alone in periods of more than $24 \mathrm{~h}$ were considered spurious and were removed from subsequent analyses (Afonso et al. 2009a). Filtered data was first examined through chronogram plots and by estimating individual residency indices. While chronograms provided a visually interpretable timeline of animals' occurrence patterns across the monitoring period, the residency index was used to evaluate the site fidelity of each individual (Afonso et al. 2008). This index ranges between 0 (no residency) and 1 (full time resident) and was calculated for the entire array $\left(\mathrm{I}_{\mathrm{T}}\right)$ and, separately, for the two monitored areas $\left(\mathrm{I}_{\mathrm{NT}}\right.$ - no-take zone; $\mathrm{I}_{\mathrm{PPA}}$ partially protected area), dividing the number of days an animal was detected $\left(\mathrm{D}_{\mathrm{D}}\right)$ by the number of days between the date of release and the last detection (i.e. detection span; $\mathrm{T}_{\mathrm{P}}$ ).

For assessing potential aggregation events, detections were pooled into 60-min bins and re-arranged in a table format, with each row representing a different date-time stamp, each column representing a different fish and presences being depicted by the corresponding receiver ID (see Gandra et al. 2017). Whenever an animal was detected at more than one receiver within a given time bin, we chose to retain the receiver ID which comprised the higher number of detections within that interval. Subsequently, co-occurrences were examined by counting the number of individuals with a similar receiver ID at each time bin and by generating level-plot images (or heat maps), that provide color-coded two-dimensional representations of the obtained patterns across each date-time period.

Spatial habitat use was analysed through the estimation of centre of activity positions (COAs) over 60-min periods. These positions were estimated independently for each tagged fish, by weighting the mean of the receiver locations by the number of detections during each time bin (see Simpfendorfer et al. 2002). The obtained coordinates were then converted to the "PT-TM06" projection (EPSG code 3763) and used to estimate individual bivariate kernel utilization distributions (KUDs; Worton 1989), using the "adehabitatHR" package (Calenge 2006). KUDs were subsequently translated into areas corresponding to $50 \%$ and $95 \%$ of 
occurrence probability, the former as a measure of core activity areas and the latter as a measure of home range areas (Abecasis et al. 2013). All distributions were calculated over a grid with $25 \times 25$ m resolution and using a fixed kernel bandwidth (h) of 150, obtained using a rule-based approach. As the least squares cross validation (LSCV) method could not be applied in the present dataset due to the proximity of position estimates (cross-validation criterion often fails to converge with clumped locations; Hemson et al. 2005) we implemented an ad-hoc approach based on the number of home range polygons, as proposed by Kie (2013). However, instead of setting a bandwidth so that a single contiguous home range was obtained for every fish, we calculated the average number of disjoint home range polygons (KUD 95\%) across a 10-step incremental sequence of kernel bandwidths (e.g. 100, 110, 120, 130, ..) and determined the bandwidth at which the curve stabilized (i.e. when the percent change was $<5 \%$ for multiple consecutive values). This alternative method was devised due to the variability of home range contours obtained for different fish and, therefore, to avoid KUD over-smoothing. Additionally, all estimates were corrected by subtracting areas overlapping with land surfaces. Changes in activity space over time were examined by calculating cumulative KUD areas for successive periods $(1,7,15,30,60,90,180$ and 270 days after tagging) and plotting the corresponding observation-area curves. It is expected that as monitoring time increases cumulative activity space will eventually reach an asymptote, indicating that no additional tracking time is required to accurately estimate core activity areas or home-ranges (VillegasRíos et al. 2013). Similarly to Rechisky and Wetherbee (2003) and Alós et al. (2011), we considered that an asymptote was reached when the percent change of the cumulative curve was less than $5 \%$ between 2 consecutive intervals. Only fish whose detections spanned for over 30 days between first and last detection were considered.

In order to investigate temporal patterns, detections were partitioned into diel and reproductive phases. Diel phases (day/night) were defined based on sunrise and sunset hours estimated for the study sites' coordinates, using algorithms provided by the National Oceanic \& Atmospheric Administration (NOAA), while reproductive seasons (resting/spawning) were defined based on available literature and through visual inspection of detections and cooccurrence plots. Additionally, as spawning of S. senegalensis breeders in captivity has been shown to be strongly linked to temperature (Dinis et al. 1999, Anguis \& Canavate 2005), we also took into account sea surface temperature (SST) fluctuations within the study location (retrieved from the NASA Multi-scale Ultra-high Resolution Daily Climatology dataset) to better define seasonality. Therefore, even though Vinagre et al. (2013) report the occurrence 
of spawning events of Senegalese soles from April to June, this period was further refined and considered to range between May and the end of June.

First, overall differences in detection frequency, distance travelled, residency, home range and core activity areas across diel and seasonal phases were inspected through box plots. Distance travelled was estimated for each $24 \mathrm{~h}$-period by dividing the sum of linear distances between consecutive COAs by the duration of each phase. Diel activity patterns were further investigated by individually estimating hourly probabilities of presence across each phase (daytime/nighttime), for each $24 \mathrm{~h}$-period. As the majority of the data was non-normally distributed and could not be transformed accordingly, differences were statistically assessed through non-parametric Wilcoxon signed-rank tests. Whenever detections were numerically sufficient for analyses (> 60 logged days), we also searched for finer-scale rhythmic patterns by applying Fast Fourier Transform (FFT) to the hourly number of individual detections, within the entire acoustic array. By decomposing data series into the frequency domain, FFT allows the identification of dominant spectral peaks that may reflect, for example, tidal $(6 \mathrm{~h}-12 \mathrm{~h})$ or diel (24h) cyclic patterns in habitat use (Afonso et al. 2009b).

Differences in home range and core activity areas across different periods were formally tested with a generalized linear mixed model (GLMM), considering diel phases and reproductive seasons as fixed factors and fish ID as a random effect (to account for repetitive measures). Factors' significance was assessed using the Satterthwaite approximation for degrees of freedom ("ImerTest"; Kuznetsova et al. 2015), and model performance was examined using plots of residuals against fitted values and residual quantile-quantile (QQ) plots (Zuur et al. 2009). The model was fitted using the "lme4" package (Bates et al. 2015). Finally, we estimated a seasonal index of reuse (IOR; Rechisky \& Wetherbee 2003) by dividing the area of overlap between resting and spawning KUDs by the area of union of both activity spaces. This index ranges between 0 (no-overlap) and 1 (complete overlap), with low IOR values indicating the occurrence of some type of seasonal migration or nomadic behaviour and higher IOR values suggesting a high site fidelity throughout the year.

\section{Results}

Between October 2010 and August 2011, a total of 366469 detections were logged by the acoustic receivers, with a mean of $21557 \pm 9780$ detections per fish. On average, tagged soles were detected during a total period of $116 \pm 30$ days (Table 1, Fig. 2), with eight individuals 
disappearing from the monitored area within 1 month, and the remaining being detected for periods up to 207 days. The number of days in which fish were detected ranged between 5 and 209, which corresponded to a residency ranging between 0.19 and 1.00 (mean $\mathrm{I}_{\mathrm{T}}=0.66$, considering the whole acoustic array). About $65 \%$ of the individuals presented a $\mathrm{I}_{\mathrm{T}}$ above 0.5 , showing that these fish spent more than half of the detection period within the monitored area. Partial residency indexes revealed a higher site fidelity to the no-take zone (mean $\mathrm{I}_{\mathrm{NT}}=0.54$ ) than to the partially protected area (mean IPPA $=0.29$ ). Indeed, twelve of the seventeen tagged soles spent more time inside the fully protected area. No relationship was found between the tagging location of the individuals and their partial residency estimates. Except for two individuals (\#10 and \#17), all fish were detected by more than 5 receivers.

The co-occurrence analysis revealed a high spatial overlap in the first days post tagging (Fig 3A), with up to 8 fish being detected simultaneously at the same receiver. After approximately 2 weeks, co-occurrences start to gradually decrease with only some occasional matches occurring mainly during daylight hours. Interestingly, between May and July, after almost 4 months without significant co-occurrences, some of the fish started to evidence signs of aggregation, mainly during the day. Approximately $90 \%$ of these co-occurrences were registered within the no-take zone, mostly between fish \#11 and fish \#13. Indeed, during the spawning season, more than $95 \%$ of these overlapping detections involved exclusively two fish, with only 28 episodes recorded of three fish being detected simultaneously on the same receiver (fish \#6, \#11 and \#13).

After pooling detections to 60-min bins, a total of 14360 COAs (mean of $845 \pm 270$ COAs per fish) was obtained and used to estimate individual KUDs. Core activity areas ranged between 0.10 and $0.38 \mathrm{~km}^{2}$, with a mean size of $0.20 \mathrm{~km}^{2}$, while home ranges ranged between 0.41 and $1.77 \mathrm{~km}^{2}$, averaging $0.99 \mathrm{~km}^{2}$ (Table 1). Analysis of the cumulative KUD areas (Fig. 4) revealed that most of the fish detected for $>30$ days exhibited relatively stable utilization areas, with asymptotes in core activity areas being reached for 6 fish and asymptotes in home range areas being reached for 8 fish.

Although a higher detection frequency was observed during the day, estimates of overall distance travelled were significantly higher during nighttimes (Fig. 5B). Likewise, fish exhibited larger home-range areas during night periods (average of $1.02 \mathrm{~km}^{2}$ versus $0.89 \mathrm{~km}^{2}$ ), even though differences were not statistically significant at an $\alpha$ level of 0.05 (Fig. 5E; Table 2). Core-activity areas did not seem to significantly differ between diel phases. Distinct diel hourly presence patterns were seen in most of the tagged soles: eleven of the individuals showed significantly higher occurrence frequencies during daytime hours (Table 3), and of the 
remaining, fish \#15 was the only one detected more frequently during nighttime hours. The FFT analysis revealed distinct cyclical patterns in all fish analysed (Fig. 6). While individuals \#3, \#11 and \#14 displayed clear peaks at the 24h-period, individuals \#2, \#6 and \#13 exhibited higher spectral densities at periods ranging between 6 and $12 \mathrm{~h}$.

Regarding reproductive seasons, we found significant differences in both coreactivity areas and home ranges (Table 2; Fig. 5), with individuals occupying larger areas during resting periods. The five individuals that were detected during both seasons (\#2, \#3, \#6, \#11, \#13 and \#14) displayed a mean IOR of $38 \%$ between resting and spawning core areas and a mean IOR of $44 \%$ between resting and spawning home-ranges (Table 4). Two individuals (\#3 and \#11) completely relocated their core-activity areas between seasons.

\section{Discussion}

\subsection{Residency and site fidelity}

As observed in many other species (e.g. Afonso et al. 2009b, Abecasis et al. 2015), we observed a large individual variability in the residency of $S$. senegalensis. These findings are in line with other flatfish studies (e.g. Loher 2008, Dando 2011, Sagarese \& Frisk 2011), which have demonstrated different movement patterns for individuals within the studied populations. Although some of the tagged fish exhibited a more nomadic behaviour, frequently moving out of the monitored area, others appear to be relatively site-attached, contradicting the perception that all flatfish are intrinsically transient due to the homogeneous and continuum nature of soft sediments (Fetterplace et al. 2016). Eight of the tagged soles (47\%) were not detected after 30 days, but it is not possible to know if these absences resulted from emigration to areas outside the LSMP, relocation within the reserve, transmitter failure or post-release mortality. Although mortality associated with the tagging procedure is assumed to be low, we cannot rule out the possibility that the external tags might have interfered with the ability of soles to camouflage themselves against the seafloor, consequently increasing mortality rate due to predation. As illegal fishing is frequent in the area due to limited enforcing and patrolling, it is also possible that some of the fish were captured by local poachers.

Despite home ranges have been documented for a variety of coral and rocky-reef species, very few studies have quantified habitat utilisation areas of soft sediment benthic species. In the present work, tagged S. senegalensis that were detected for periods $>30$ days 
were found to spend $95 \%$ of their time within an average area of $0.88 \pm 0.46 \mathrm{~km}^{2}$ and occupy average core activity areas of $0.19 \pm 0.10 \mathrm{~km}^{2}$ (50\% KUD). Although slightly larger than those estimated for a reef-attached species within the same MPA (Diplodus sargus; Abecasis et al. 2015), these habitat utilisation areas are still considerably lower than the total monitored area, (approximately $3 \mathrm{~km}^{2}$ ). Given that most habitat utilisation areas appeared to stabilize throughout the monitoring period, these results reinforce the sedentary behaviour exhibited by some of these fish.

Interestingly, the majority of the tagged individuals displayed a higher attachment to the no-take zone than to the partially protected area. As the proportion of monitored habitat was similar in both areas, this result might be either an artefact of the small sample size or an indication that the former holds a higher percentage of preferred habitats (as modelled in Abecasis et al. 2014b). Indeed, even though bottom substrates are relatively similar, differences in macrobenthos assemblages across the LSMP have been observed in past surveys (Fig. 1C; Henriques et al. 2015). Given the relatively young age of the LSMP (the use of fishing nets in the NT and PPAs only ceased in 2007), behavioural responses to the reserve environment are unlikely.

\subsection{Diel activity patterns}

Despite the higher number of detections registered during daytime, our results seem to corroborate the presumed nocturnal activity rhythm of S. senegalensis. Indeed, even though not all tagged individuals exhibited marked diel patterns, the larger nighttime home range areas coupled with the larger distances travelled after dark support this hypothesis and contradict the diurnal periodicity observed in detections. It is known that extrapolating diel behaviours from telemetry data is not always a linear task, and thus extra caution should be taken (Payne et al. 2010). While environmental factors such as temperature, wind speed and background noise might significantly affect detectability of the tagged animals (Kessel et al. 2014), range tests did not evidence significant differences between day and night (Table 3 - control), and thus we hypothesize that the higher detection frequencies observed during diurnal periods may in fact be associated with the reduced mobility of resting fish. Even though soles are known to exhibit "burying" behaviour during resting periods (Carazo et al. 2016), the dorsal positioning of the transmitter could have enabled the signal to be successfully detected ( $S$. senegalensis often leave the eyes and upper nostril exposed which would allow the tag to lie above the sediment; Velez et al. 2005, Grothues et al. 2012). Contrastingly, flatfish swimming along the bottom 
could increase the probability of signal occlusion due to the irregularity of the substrate and features such as rock outcrops or algae fronds, known to frequently occur within the marine park (Cunha et al. 2014). In fact, Topping et al. (2006) observed a similar phenomenon, with detection frequency being negatively correlated with the rate of movement of another benthic species (Semicossyphus pulcher). Although we did not find any evidence of directional movements between inner and outer receivers, it is also possible that soles perform diel migrations to deeper or shallower areas not covered by the acoustic array. Recently, Humphries et al. (2017) detected diel vertical movements (DVM) in benthic predators and therefore is possible that soles carry out similar nekton-benthic displacements as a response to varying levels of predation risk or prey availability. These interpretations are further supported by previous studies on S. senegalensis juveniles and adult specimens kept in captivity, which observed not only higher locomotor activity during nocturnal periods (Bayarri et al. 2004), but also higher metabolic rates (Castanheira et al. 2011), stronger spawning activity (Oliveira et al. 2009) and more frequent feeding after dark (Boluda Navarro et al. 2009). Moreover, Fatsini et al. (2017) described daytime burying behaviours in dominant soles under experimental conditions. If these results are found to accurately represent $S$. senegalensis diel patterns in the wild, then they would point towards a high behavioural uniformity within the Soleidae family, as nocturnal activity rhythms have been also described for the closely-related common sole, Solea solea (Sureau \& Lagardére 1991), whiskered sole, Monochirus hispidus (Amaral \& Cabral 2004) and solenette, Buglossidium luteum (de Groot 1971).

In addition to the $24 \mathrm{~h}$ periodicity associated with these diel shifts in behaviour, the FFT analysis also revealed peaks at $6 \mathrm{~h}$ and $12 \mathrm{~h}$ periods for some of the individuals, which might suggest that tidal cycles also influence soles activity. Given that tidal migrations have been identified in other flatfishes (e.g. Harden Jones et al. 1979, Greer Walker et al. 1980), it is conceivable that Senegalese soles exhibit similar behavioural traits, either to take advantage of additional feeding grounds or as a way of more effective transportation (i.e. selective tidal stream transport). Further studies integrating depth-sensing tags or active telemetry methodologies are required to better examine these daily movement patterns.

\subsection{Seasonal cycles}

Senegalese soles exhibited significantly lower home range and core activity areas between May and June, which together with the more frequent co-occurrences and reduced movement rates, point towards the existence of a behavioural shift during the reproductive season. These 
patterns also appeared to closely match the increase in sea surface temperature observed during this period $\left(>18^{\circ} \mathrm{C}\right)$, supporting previous aquaculture-based studies. Oliveira et al. (2011) suggested that temperature is indeed the main cue used by S. senegalensis to synchronize reproductive activity and gonad development, while Anguis and Canavate (2005) reported maximum daily fecundities between $18^{\circ}$ and $19^{\circ} \mathrm{C}$.

While two of the tagged soles remained mostly inside the marine reserve during the spawning season (fish \#11 and \#13), others went undetected for most of the days between May and the June (fish \# 2 and \#3). Consequently, it is possible that some of the individuals undergo seasonal migrations to spawning grounds not covered by our acoustic array. Interestingly, divergent reproductive behaviours within sympatric contingents have also been observed in another flatfish, the winter flounder (Pseudopleuronectes americanus), with part of the population remaining in coastal habitats and some individuals migrating towards estuarine waters (DeCelles \& Cadrin 2010). There are however, two caveats that should be mentioned regarding our results: first, the small sample of individuals successfully monitored during the spawning season, and second, the uncertainty associated with estimating fish interactions/encounters from passive telemetry data. As noted by Mourier et al. (2017), two fish detected at the same receiver, in the same time bin, might not be interacting and instead be several meters apart due to the extended detection range of the acoustic system (approximately $300 \mathrm{~m}$ in the present study).

Taking these limitations in consideration, we could speculate that the large percentage of single co-occurrences might be associated with the S. senegalensis strictly paired spawning behaviour observed by Carazo et al. (2016). Likewise, females were observed to exhibit a predominately stationary behaviour during spawning periods, while males were observed to increase overall activity, which could perhaps explain the differing levels of home range reuse observed. Alternative telemetry configurations comprising short-range proximity loggers (e.g. Guttridge et al. 2010) or high-resolution positioning receivers (e.g. Vemco VPS; Espinoza et al. 2011) could be used in future studies to better investigate these fine-scale interaction dynamics.

\subsection{Implications for management}

This study supports the results of Abecasis et al. (2014a) and provides novel information on the spatial behaviour of Senegalese soles that has implications for the management of this species. First, the observed residency patterns coupled with the estimated home ranges suggests 
that small size $(<5 \mathrm{~km})$ no-take areas encompassing soft sediment habitat can offer adequate protection for at least part of the S. senegalensis population. Indeed, the observed variability in residency indicates that while some fishes are more site attached, others are probably more vagile and therefore the spillover effect of some mature individuals is very likely. Secondly, the diel behavioural patterns observed emphasize the importance of an efficient law enforcement within the marine park. As soles are presumably more active during nightime hours and some illegal fishing activities are known to take place during the night (Reis et al. 2004), the species can be potentially more vulnerable to illegal exploitation. Finally, the results observed during the spawning season provide evidence that shifts in space use likely exist in association with reproductive activity, arguing the need for additional studies comprising a larger number of fish. Then, all of this information could be used to guide the management of S. senegalensis to ensure its sustainability on the long-term.

\section{Acknowledgments}

This study was performed according to national Portuguese laws for the use of vertebrates in research. No animals were sacrificed, and procedures for reduction, replacement and refinement were thoroughly adopted. We are grateful to the Biomares team for their help with acoustic receivers' deployment and retrieval and to Inês Sousa and Joaquim "Quinel" for their help during the tagging procedures. This research was partially supported by the EU LIFEBIOMARES Project (LIFE06 NAT/P/000192) and by the Portuguese Foundation for Science and Technology/Ministry of Education and Science (FCT/MCTES-MEC) through individual support to D.A. (SFRH/BD/46286/2008 and SFRH/BPD/95334/2013) and the project CCMAR/Multi/04326/2013.

\section{References}

Abecasis D, Afonso P, Erzini K (2014a) Can small MPAs protect local populations of a coastal flatfish, Solea senegalensis? Fisheries Management and Ecology 21:175-185

Abecasis D, Afonso P, Erzini K (2014b) Combining multispecies home range and distribution models aids assessment of MPA effectiveness. Marine Ecology Progress Series 513:155-169 
Abecasis D, Afonso P, Erzini K (2015) Changes in movements of white seabream (Diplodus sargus) during the reproductive season. Estuarine, Coastal and Shelf Science 167:499503

Abecasis D, Bentes L, Lino PG, Santos MN, Erzini K (2013) Residency, movements and habitat use of adult white sea bream (Diplodus sargus) between natural and artificial reefs. Estuarine, Coastal and Shelf Science 118:80-85

Afonso P, Fontes J, Guedes R, Tempera F, Holland KN, Santos RS (2009a) A multi-scale study of red porgy movements and habitat use, and its application to the design of marine reserve networks. In: Nielsen JL, Arrizabalaga H, Fragoso N, Hobday A, Lutcavage M, Sibert J (eds) Tagging and Tracking of Marine Animals with Electronic Devices. Springer, Dordrecht

Afonso P, Fontes J, Holland KN, Santos RS (2008) Social status determines behaviour and habitat usage in a temperate parrotfish: implications for marine reserve design. Marine Ecology Progress Series 359:215-227

Afonso P, Fontes J, Holland KN, Santos RS (2009b) Multi-scale patterns of habitat use in a highly mobile reef fish, the white trevally Pseudocaranx dentex, and their implications for marine reserve design. Marine Ecology Progress Series 381:273-286

Alós J, March D, Palmer M, Grau A, Morales-Nin B (2011) Spatial and temporal patterns in Serranus cabrilla habitat use in the NW Mediterranean revealed by acoustic telemetry. Mar Ecol Prog Ser 427:173-186

Amaral V, Cabral HN (2004) Ecology of the whiskered sole in the Sado Estuary, Portugal. Journal of Fish Biology 64:460-474

Anguis V, Canavate JP (2005) Spawning of captive Senegal sole (Solea senegalensis) under a naturally fluctuating temperature regime. Aquaculture 243:133-145

Bates D, Mächler M, Bolker B, Walker S (2015) Fitting Linear Mixed-Effects Models Using \{lme4\}. Journal of Statistical Software 67:1-48

Bayarri MJ, Muñoz-Cueto JA, López-Olmeda JF, Vera LM, Rol De Lama MA, Madrid JA, Sánchez-Vázquez FJ (2004) Daily locomotor activity and melatonin rhythms in Senegal sole (Solea senegalensis). Physiology \& behavior 81:577-583

Bégout Anras ML, Covès D, Dutto G, Laffargue P, Lagardère F (2003) Tagging juvenile seabass and sole with telemetry transmitters: medium-term effects on growth. Ices Journal of Marine Science 60:1328-1334

Boluda Navarro D, Rubio VC, Luz RK, Madrid JA, Sánchez-Vázquez FJ (2009) Daily feeding rhythms of Senegalese sole under laboratory and farming conditions using self-feeding systems. Aquaculture 291:130-135

Cabral HN (2000) Comparative feeding ecology of sympatric Solea solea and S. senegalensis, within the nursery areas of the Tagus estuary, Portugal. Journal of Fish Biology 57:1550-1562 
Calenge C (2006) The package "adehabitat" for the R software: a tool for the analysis of space and habitat use by animals. Ecological Modelling 197:516-519

Carazo I, Chereguini O, Martín I, Huntingford F, Duncan NJ (2016) Reproductive ethogram and mate selection in captive wild Senegalese sole (Solea senegalensis). Spanish Journal of Agricultural Research 14:0401

Castanheira MF, Martins CIM, Engrola S, Conceição LEC (2011) Daily oxygen consumption rhythms of Senegalese sole Solea senegalensis (Kaup, 1858) juveniles. Journal of Experimental Marine Biology and Ecology 407:1-5

Cunha AH, Erzini K, Serrão EA, Gonçalves E, Borges R, Henriques M, Henriques V, Guerra M, Duarte C, Marbá N (2014) Biomares, a LIFE project to restore and manage the biodiversity of Prof. Luiz Saldanha Marine Park. Journal of Coastal Conservation 18:643-655

Dando PR (2011) Site fidelity, homing and spawning migrations of flounder Platichthys flesus in the Tamar estuary, South West England. Marine Ecology Progress Series 430:183196

de Groot SJ (1971) On the interrelationships between morphology of the alimentary tract, food and feeding behaviour in flatfishes (Pisces: Pleuronectiformes). Netherlands Journal of Sea Research 5:121-196

DeCelles GR, Cadrin SX (2010) Movement patterns of winter flounder (Pseudopleuronectes americanus) in the southern Gulf of Maine: observations with the use of passive acoustic telemetry. Fishery Bulletin 108:408-419

Dinis MT, Ribeiro L, Soares F, Sarasquete C (1999) A review on the cultivation potential of Solea senegalensis in Spain and in Portugal. Aquaculture 176:27-38

Espinoza M, Farrugia TJ, Webber DM, Smith F, Lowe CG (2011) Testing a new acoustic telemetry technique to quantify long-term, fine-scale movements of aquatic animals. Fisheries Research 108:364-371

Fatsini E, Rey S, Ibarra-Zatarain Z, Mackenzie S, Duncan NJ (2017) Dominance behaviour in a non-aggressive flatfish, Senegalese sole (Solea senegalensis) and brain mRNA abundance of selected transcripts. PLoS ONE 12:e0184283

Fetterplace LC, Davis AR, Neilson JM, Taylor MD, Knott NA (2016) Active acoustic tracking suggests that soft sediment fishes can show site attachment: a preliminary assessment of the movement patterns of the blue-spotted flathead (Platycephalus caeruleopunctatus). Animal Biotelemetry 4:15

Firmino J, Carballo C, Armesto P, Campinho MA, Power DM, Manchado M (2017) Phylogeny, expression patterns and regulation of DNA Methyltransferases in early development of the flatfish, Solea senegalensis. BMC Developmental Biology 17:11

Gandra M, Fontes J, Afonso P (2017) Patterns of intra and interspecific association in two predatory reef fishes at a remote seamount. Manuscript in preparation 
Gell FR, Roberts CM (2003) Benefits beyond boundaries: the fishery effects of marine reserves. Trends in Ecology \& Evolution 18:448-455

Greer Walker M, Riley JD, Emerson LS (1980) On the movements of sole (Solea solea) and dogfish (Scyliorhinus canicula) tracked off the East Anglian coast Netherlands Journal of Sea Research 14:66-77

Grothues TM, Able KW, Pravatiner JH (2012) Winter flounder (Pseudopleuronectes americanus Walbaum) burial in estuaries: acoustic telemetry triumph and tribulation. Journal of Experimental Marine Biology and Ecology 438:125-136

Grüss A, Robinson J, Heppell SS, Heppell SA, Semmens BX (2014) Conservation and fisheries effects of spawning aggregation marine protected areas: what we know, where we should go, and what we need to get there. ICES Journal of Marine Science 71:15151534

Guttridge TL, Gruber SH, Krause J, Sims DW (2010) Novel acoustic technology for studying free-ranging shark social behaviour by recording individuals' interactions. PLoS ONE 5:e9324

Harden Jones FR, Arnold GP, Greer Walker M, Scholes P (1979) Selective tidal stream transport and the migration of plaice (Pleuronectes platessa L.) in the southern North Sea. Journal du Conseil 38:331-337

Hemson G, Johnson P, South A, Kenward R, Ripley R, Macdonald D (2005) Are kernels the mustard? Data from global positioning system (GPS) collars suggests problems for kernel home-range analyses with least-squares cross-validation. Journal of Animal Ecology 74:455-463

Henriques V, Guerra MT, Mendes B, Gaudêncio MJ, Fonseca P (2015) Benthic habitat mapping in a Portuguese marine protected area using EUNIS: an integrated approach. Journal of Sea Research 100:77-90

Horta e Costa B, Erzini K, Caselle JE, Folhas H, Gonçalves EJ (2013) 'Reserve effect' within a temperate marine protected area in the north-eastern Atlantic (Arrábida Marine Park, Portugal). Marine Ecology Progress Series 481:11-24

Humphries NE, Simpson SJ, Sims DW (2017) Diel vertical migration and central place foraging in benthic predators. Marine Ecology Progress Series 582:163-180

Kessel ST, Cooke SJ, Heupel MR, Hussey NE, Simpfendorfer CA, Vagle S, Fisk AT (2014) A review of detection range testing in aquatic passive acoustic telemetry studies. Reviews in Fish Biology and Fisheries 24:199-218

Kie JG (2013) A rule-based ad hoc method for selecting a bandwidth in kernel home-range analyses. Animal Biotelemetry 1:1-12

Kuznetsova A, Brockhoff PB, Christensen RHB (2015) lmerTest: Tests for random and fixed effects for linear mixed effect models (lmer objects of lme4 package), R package version 2.0-33. Available at: http://cran.r-project.org/package=lmerTest 
Loher T (2008) Homing and summer feeding site fidelity of Pacific halibut (Hippoglossus stenolepis) in the Gulf of Alaska, established using satellite-transmitting archival tags. Fisheries Research 92:63-69

Mourier J, Bass NC, Guttridge TL, Day J, Brown C (2017) Does detection range matter for inferring social networks in a benthic shark using acoustic telemetry? Royal Society Open Science 4:170485

Oliveira C, Mañanós E, Ramos J, Sánchez-Vázquez FJ (2011) Impact of photoperiod manipulation on day/night changes in melatonin, sex steroids and vitellogenin plasma levels and spawning rhythms in Senegal sole, Solea senegalensis. Comparative Biochemistry and Physiology - Part A: Molecular \& Integrative Physiology 159:291295

Oliveira C, Vera LM, López-Olmeda JF, Guzmán JM, Mañanós E, Ramos J, Sánchez-Vázquez FJ (2009) Monthly day/night changes and seasonal daily rhythms of sexual steroids in Senegal sole (Solea senegalensis) under natural fluctuating or controlled environmental conditions. Comparative Biochemistry and Physiology Part A: Molecular \& Integrative Physiology 152:168-175

Payne NL, Gillanders BM, Webber DM, Semmens JM (2010) Interpreting diel activity patterns from acoustic telemetry: the need for controls. Marine Ecology Progress Series 419:295-301

Quéro JC, Desoutter M, Lagardère F (1986) Soleidae. In: Whitehead PJP, Bauchot M-L, Hureau J-C, Nielsen J, Tortonese E (eds) Fishes of the North-eastern Atlantic and the Mediterranean. UNESCO, Paris

R Core Team (2017) R: A language and environment for statistical computing. R Foundation for Statistical Computing, Vienna, Austria.

Rechisky EL, Wetherbee BM (2003) Short-term movements of juvenile and neonate sandbar sharks, Carcharhinus plumbeus, on their nursery grounds in Delaware Bay. Environmental Biology of Fishes 68:113-128

Reis C, Santos F, Venceslau T (2004) Avaliação da Proposta do Plano de Ordenamento do Parque Natural da Arrábida-Componente Parque Marinho Luiz Saldanha (Vol. II). Lisboa, Instituto de Conservação da Natureza, Instituto Superior de Agronomia, Gabinete Coordenador do Programa Finisterra

Roberts CM, Bohnsack JA, Gell F, Hawkins JP, Goodridge R (2001) Effects of marine reserves on adjacent fisheries. Science 294:1920-1923

Russ GR, Miller KI, Rizzari JR, Alcala AC (2015) Long-term no-take marine reserve and benthic habitat effects on coral reef fishes. Marine Ecology Progress Series 529:233248

Sadovy Y, Domeier M (2005) Are aggregation-fisheries sustainable? Reef fish fisheries as a case study. Coral Reefs 24:254-262

Sagarese SR, Frisk MG (2011) Movement patterns and residence of adult winter flounder within a Long Island estuary. Marine and Coastal Fisheries 3:295-306 
Simpfendorfer CA, Heupel MR, Hueter RE (2002) Estimation of short-term centers of activity from an array of omnidirectional hydrophones and its use in studying animal movements. Canadian Journal of Fisheries and Aquatic Sciences 59:23-32

Sureau D, Lagardére JP (1991) Coupling of heart rate and locomotor activity in sole, Solea solea (L.), and bass, Dicentrarchus labrax (L.), in their natural environment by using ultrasonic telemetry. Journal of Fish Biology 38:399-405

Teixeira CM, Cabral HN (2010) Comparative analysis of the diet, growth and reproduction of the soles, Solea solea and Solea senegalensis, occurring in sympatry along the Portuguese coast. Journal of the Marine Biological Association of the United Kingdom 90:995-1003

Topping DT, Lowe CG, Caselle JE (2006) Site fidelity and seasonal movement patterns of adult California sheephead Semicossyphus pulcher (Labridae): an acoustic monitoring study. Marine Ecology Progress Series 326:257-267

Vandeperre F, Higgins RM, Sánchez-Meca J, Maynou F, Goñi R, Martín-Sosa P, Pérez-Ruzafa A, Afonso P, Bertocci I, Crec'hriou R, D’Anna G, Dimech M, Dorta C, Esparza O, Falcón JM, Forcada A, Guala I, Le Direach L, Marcos C, Ojeda-Martínez C, Pipitone C, Schembri PJ, Stelzenmüller V, Stobart B, Santos RS (2011) Effects of no-take area size and age of marine protected areas on fisheries yields: a meta-analytical approach. Fish and Fisheries 12:412-426

Vasconcelos RP, Reis-Santos P, Maia A, Fonseca V, França S, Wouters N, Costa MJ, Cabral HN (2010) Nursery use patterns of commercially important marine fish species in estuarine systems along the Portuguese coast. Estuarine, Coastal and Shelf Science 86:613-624

Velez Z, Hubbard PC, Barata EN, Canário AVM (2005) Evidence for functional asymmetry in the olfactory system of the Senegalese sole (Solea senegalensis). Physiological and Biochemical Zoology 78:756-765

Villegas-Ríos D, Alós J, March D, Palmer M, Mucientes G, Saborido-Rey F (2013) Home range and diel behavior of the ballan wrasse, Labrus bergylta, determined by acoustic telemetry. Journal of Sea Research 80:61-71

Vinagre C, Fonseca V, Cabral HN, Costa MJ (2006a) Habitat suitability index models for the juvenile soles, Solea solea and Solea senegalensis, in the Tagus estuary: defining variables for species management. Fisheries Research 82:140-149

Vinagre C, França S, Cabral HN (2006b) Diel and semi-lunar patterns in the use of an intertidal mudflat by juveniles of Senegal sole, Solea senegalensis. Estuarine, Coastal and Shelf Science 69:246-254

Vinagre C, Maia A, Amara R, Cabral HN (2013) Spawning period of Senegal sole, Solea senegalensis, based on juvenile otolith microstructure. Journal of Sea Research 76:8993

Worton BJ (1989) Kernel methods for estimating the utilization distribution in home-range studies. Ecology 70:164-168 
Zuur AF, Ieno EN, Walker NJ, Saveliev AA, Smith GM (2009) Mixed Effects Models and Extensions in Ecology with R. Springer, New York

Table 1. Summary data for tagged individuals. $\mathrm{T}_{\mathrm{P}}-$ total period of detection (days between 1 st and last detection); $\mathrm{D}_{\mathrm{D}}-$ days with detections; LI - linearity index; $\mathrm{I}_{\mathrm{T}}$ - total residency index; $\mathrm{I}_{\mathrm{NT}}$ - no-take zone residency; $\mathrm{I}_{\mathrm{PPA}}$ - partially protected area residency; KUD 50\% - kernel utilisation distributions corresponding to core utilisation area $\left(\mathrm{km}^{2}\right)$; KUD 95\% - kernel utilisation distribution corresponding to home range area $\left(\mathrm{km}^{2}\right)$. Mean values are displayed on the bottom.

\begin{tabular}{|c|c|c|c|c|c|c|c|c|c|c|c|c|}
\hline \multirow{2}{*}{$\begin{array}{l}\text { Fish } \\
\text { ID }\end{array}$} & \multirow{2}{*}{$\begin{array}{l}\text { Length } \\
\text { (cm) }\end{array}$} & \multirow{2}{*}{$\begin{array}{l}\text { Tagging } \\
\text { site }\end{array}$} & \multirow{2}{*}{$\begin{array}{c}\text { Day } \\
\text { tagged }\end{array}$} & \multirow{2}{*}{$\begin{array}{c}\text { Last } \\
\text { detection }\end{array}$} & \multirow{2}{*}{$\begin{array}{l}\text { № of } \\
\text { COAs }\end{array}$} & \multirow{2}{*}{$\mathbf{T}_{\mathrm{P}}$} & \multirow{2}{*}{$\mathrm{D}_{\mathrm{D}}$} & \multicolumn{3}{|c|}{$I_{R}$} & \multicolumn{2}{|c|}{ KUD } \\
\hline & & & & & & & & $\mathbf{I}_{\mathbf{T}}$ & $\mathrm{I}_{\mathrm{NT}}$ & IPPA & $50 \%$ & $95 \%$ \\
\hline$\# 1$ & 38.8 & NT & $27 / 10 / 2010$ & $07 / 11 / 2010$ & 188 & 12 & 12 & 1.00 & 0.83 & 0.25 & 0.31 & 1.52 \\
\hline$\# 2$ & 40.6 & NT & $27 / 10 / 2010$ & $13 / 08 / 2011$ & 867 & 291 & 95 & 0.33 & 0.05 & 0.32 & 0.14 & 1.22 \\
\hline \#3 & 30.2 & NT & $27 / 10 / 2010$ & $15 / 08 / 2011$ & 4249 & 293 & 209 & 0.71 & 0.16 & 0.71 & 0.11 & 0.51 \\
\hline$\# 4$ & 32.5 & NT & $27 / 10 / 2010$ & $31 / 10 / 2010$ & 90 & 5 & 5 & 1.00 & 1.00 & 0.40 & 0.23 & 1.29 \\
\hline$\# 5$ & 39.8 & NT & $27 / 10 / 2010$ & $06 / 02 / 2011$ & 200 & 103 & 20 & 0.19 & 0.17 & 0.06 & 0.38 & 1.77 \\
\hline$\# 6$ & 41.1 & NT & $27 / 10 / 2010$ & $13 / 08 / 2011$ & 691 & 291 & 75 & 0.26 & 0.15 & 0.20 & 0.24 & 0.81 \\
\hline$\# 7$ & 34.3 & NT & $27 / 10 / 2010$ & $08 / 11 / 2010$ & 203 & 13 & 13 & 1.00 & 1.00 & 0.69 & 0.19 & 1.21 \\
\hline
\end{tabular}




\begin{tabular}{|c|c|c|c|c|c|c|c|c|c|c|c|c|}
\hline \#8 & 36.6 & NT & $27 / 10 / 2010$ & $15 / 11 / 2010$ & 60 & 20 & 7 & 0.35 & 0.35 & 0.05 & 0.21 & 1.21 \\
\hline$\# 9$ & 32.0 & NT & 27/10/2010 & 03/12/2010 & 342 & 38 & 23 & 0.61 & 0.37 & 0.39 & 0.22 & 1.10 \\
\hline \#10 & 30.6 & NT & $27 / 10 / 2010$ & 05/11/2010 & 64 & 10 & 8 & 0.80 & 0.80 & 0.00 & 0.12 & 0.63 \\
\hline$\# 11$ & 31.4 & NT & 27/10/2010 & 28/06/2011 & 2211 & 245 & 183 & 0.75 & 0.62 & 0.40 & 0.25 & 1.11 \\
\hline$\# 12$ & 38.1 & PPA & 28/10/2010 & $31 / 01 / 2011$ & 604 & 96 & 49 & 0.51 & 0.51 & 0.07 & 0.11 & 0.53 \\
\hline \#13 & 36.6 & PPA & 28/10/2010 & $16 / 08 / 2011$ & 2095 & 293 & 113 & 0.39 & 0.38 & 0.01 & 0.10 & 0.41 \\
\hline \#14 & 40.0 & PPA & 28/10/2010 & $24 / 05 / 2011$ & 1538 & 209 & 103 & 0.49 & 0.10 & 0.48 & 0.11 & 0.45 \\
\hline \#15 & 38.0 & PPA & 28/10/2010 & 09/11/2010 & 237 & 13 & 13 & 1.00 & 1.00 & 0.38 & 0.21 & 0.79 \\
\hline \#16 & 40.0 & PPA & 28/10/2010 & $16 / 11 / 2010$ & 288 & 20 & 18 & 0.90 & 0.75 & 0.45 & 0.36 & 1.74 \\
\hline \multirow[t]{2}{*}{$\# 17$} & 37.3 & PPA & 28/10/2010 & $16 / 11 / 2010$ & 433 & 20 & 20 & 1.00 & 1.00 & 0.00 & 0.11 & 0.50 \\
\hline & & & & & 845 & 116 & 57 & 0.66 & 0.54 & 0.29 & 0.20 & 0.99 \\
\hline
\end{tabular}

Table 2. Results of the Generalized Linear Mixed Model (GLMM) fitted to test the effect of diel phase (day vs night) and reproductive season (resting vs spawning) on core activity (KUD 50\%) and home range (KUD 95\%) areas. Fish ID was used as a random factor. Significance codes: $* * * \mathrm{p}<0.001, * * \mathrm{p}<0.01, * \mathrm{p}<0.05, \cdot \mathrm{p}<0.10$.

\begin{tabular}{lccccc}
\hline & Estimate & Std. error & $\boldsymbol{t}$ value & $\operatorname{Pr}(>|t|)$ & Significance \\
\hline KUD 50\% & & & & & \\
$\quad$ Intercept & 0.186 & 0.020 & 9.10 & $<0.001$ & $* *$ \\
Diel (night) & 0.010 & 0.006 & 1.55 & 0.134 & \\
Season (spawning) & -0.033 & 0.010 & -3.29 & 0.003 & $*$ \\
KUD 95\% & & & & \\
Intercept & 0.888 & 0.104 & 8.53 & $<0.001$ & $*$ \\
Diel (night) & 0.111 & 0.057 & 1.93 & 0.066 & $*$ \\
Season (spawning) & -0.299 & 0.086 & -3.46 & 0.002 & $* *$ \\
\hline
\end{tabular}

Table 3. Diel analysis conducted for the 17 tagged soles and the control tag. On the left, differences between daytime and night-time hourly presence probabilities are shown for each individual, together with the corresponding $95 \%$ confidence intervals (i.e. positive values indicate higher presence probabilities during daytime hours, while negative values indicate higher presence probabilities during night-time hours). On the right, probabilities are shown separately for each phase (means \pm standard errors), together with Wilcoxon signed-rank test results. Significance codes: $* * * \mathrm{p}<$ $0.001, * * \mathrm{p}<0.01, * \mathrm{p}<0.05$. 


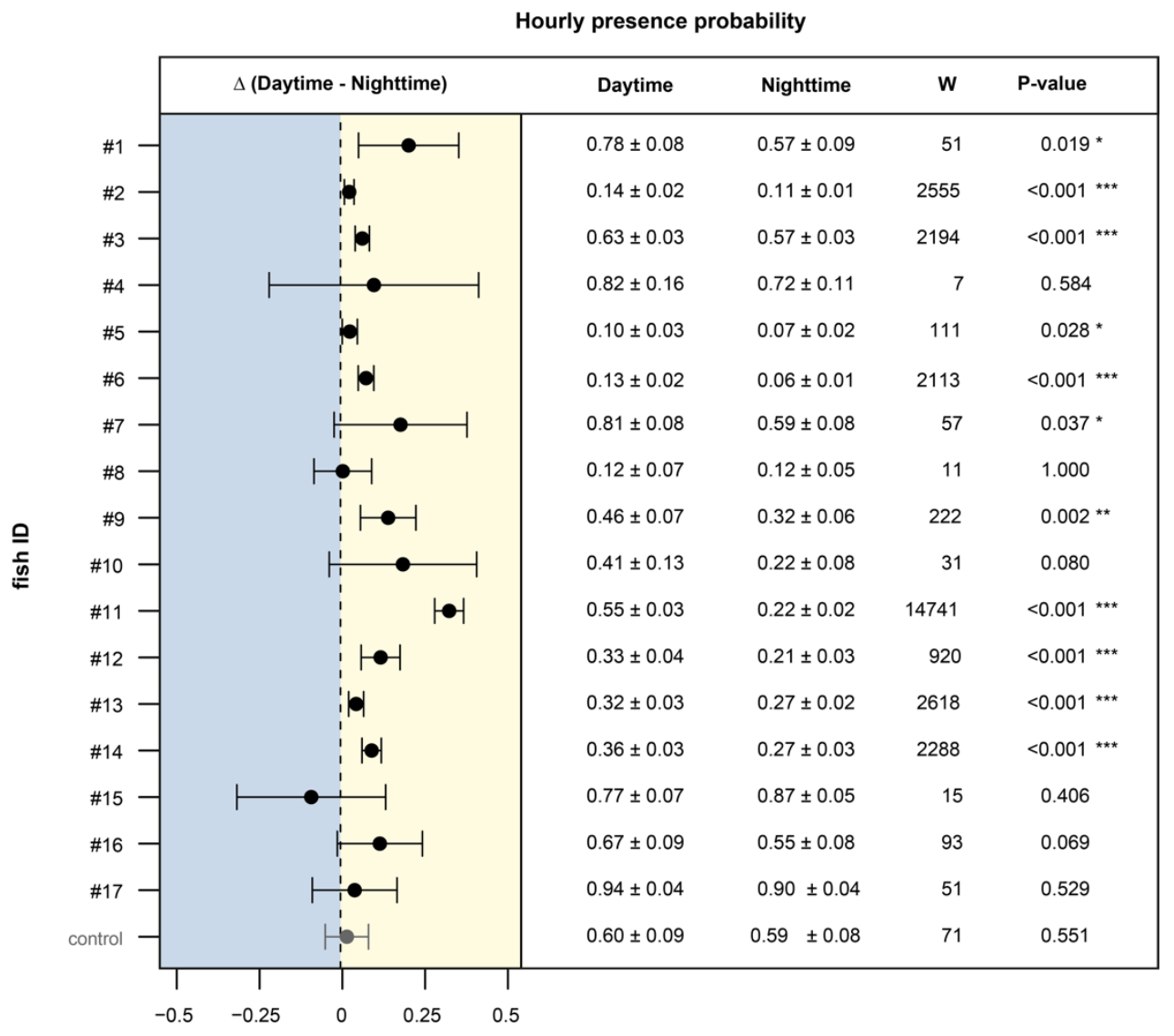

Table 4. Kernel utilisation distributions corresponding to core utilisation (KUD 50\%) and home range areas (KUD 95\%) during the resting and spawning seasons (in $\mathrm{km}^{2}$ ). IOR corresponds to the index of reuse between both seasons (i.e. \% of overlap between resting and spawning areas). Mean values are displayed on the bottom.

\begin{tabular}{|c|c|c|c|c|c|c|}
\hline \multirow{2}{*}{ Fish ID } & \multicolumn{3}{|c|}{ KUD 50\% } & \multicolumn{3}{|c|}{ KUD 95\% } \\
\hline & Resting & Spawning & IOR & Resting & Spawning & IOR \\
\hline
\end{tabular}




\begin{tabular}{llllllll}
$\# 2$ & 0.15 & 0.10 & 0.66 & 1.26 & 0.42 & 0.34 \\
$\# 3$ & 0.11 & 0.09 & 0.00 & 0.51 & 0.30 & 0.23 \\
$\# 6$ & 0.24 & 0.17 & 0.39 & 0.82 & 0.49 & 0.60 \\
$\# 11$ & 0.15 & 0.12 & 0.00 & 0.84 & 0.79 & 0.25 \\
$\# 13$ & 0.11 & 0.09 & 0.83 & 0.46 & 0.33 & 0.76 \\
\hline
\end{tabular}




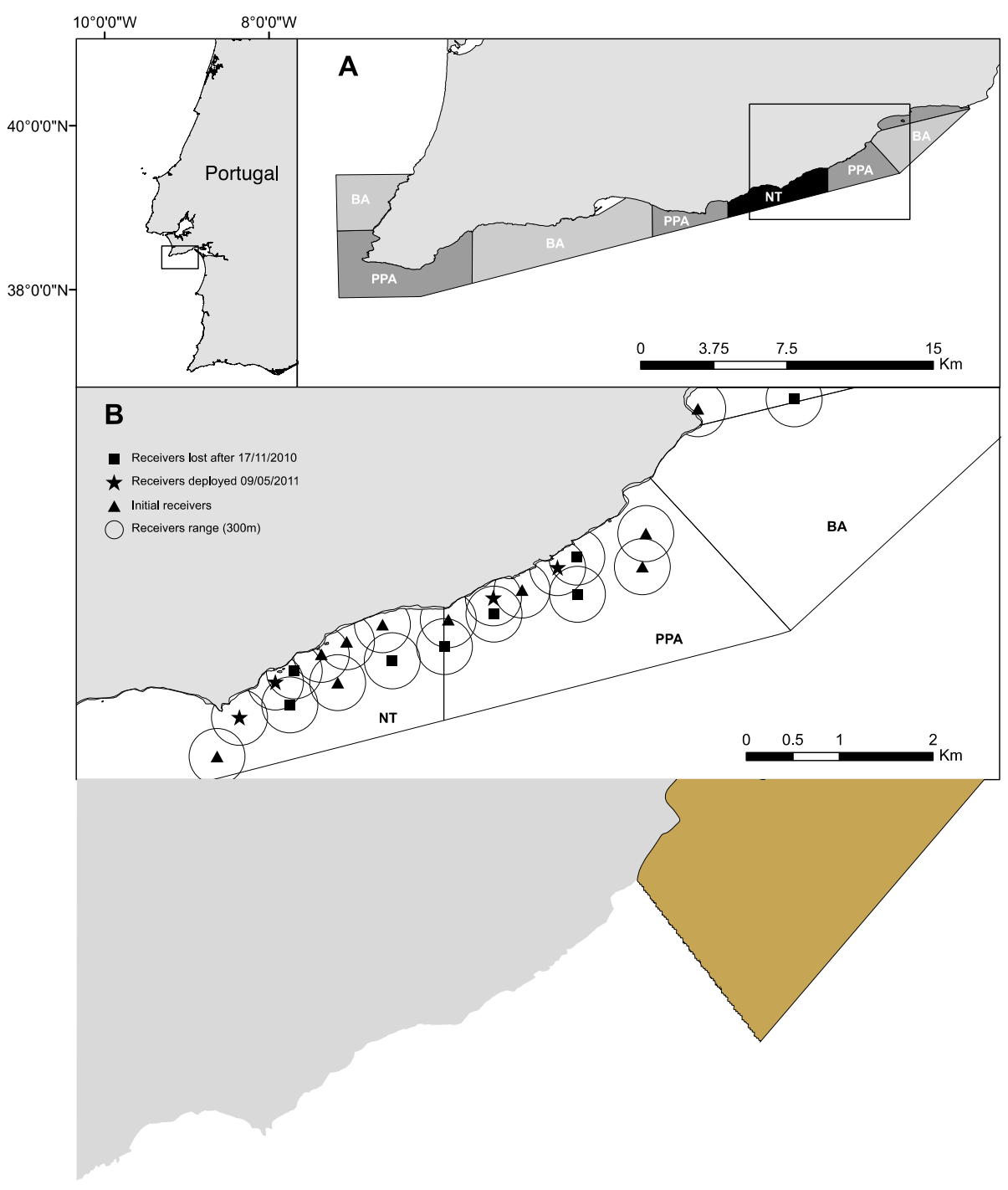

Figure 1. Map of the Professor Luiz Saldanha Marine Park (A), Portugal, depicting the location of the no-take zone (i.e. fully protected area; NT), the partially protected areas (PPA) and the buffer areas (BA). Location of the acoustic receivers and respective ranges are shown in $\mathrm{B}$. Triangles represent the initial location of the receivers, squares symbolize receivers that were lost after 17 November 2010, and stars stand for new receivers deployed on 9 May 2011. Fish capture locations (asterisks) and habitat types adapted from Henriques et al. (2015) are exhibited in C, together with the correspondent EUNIS habitat classification codes. 


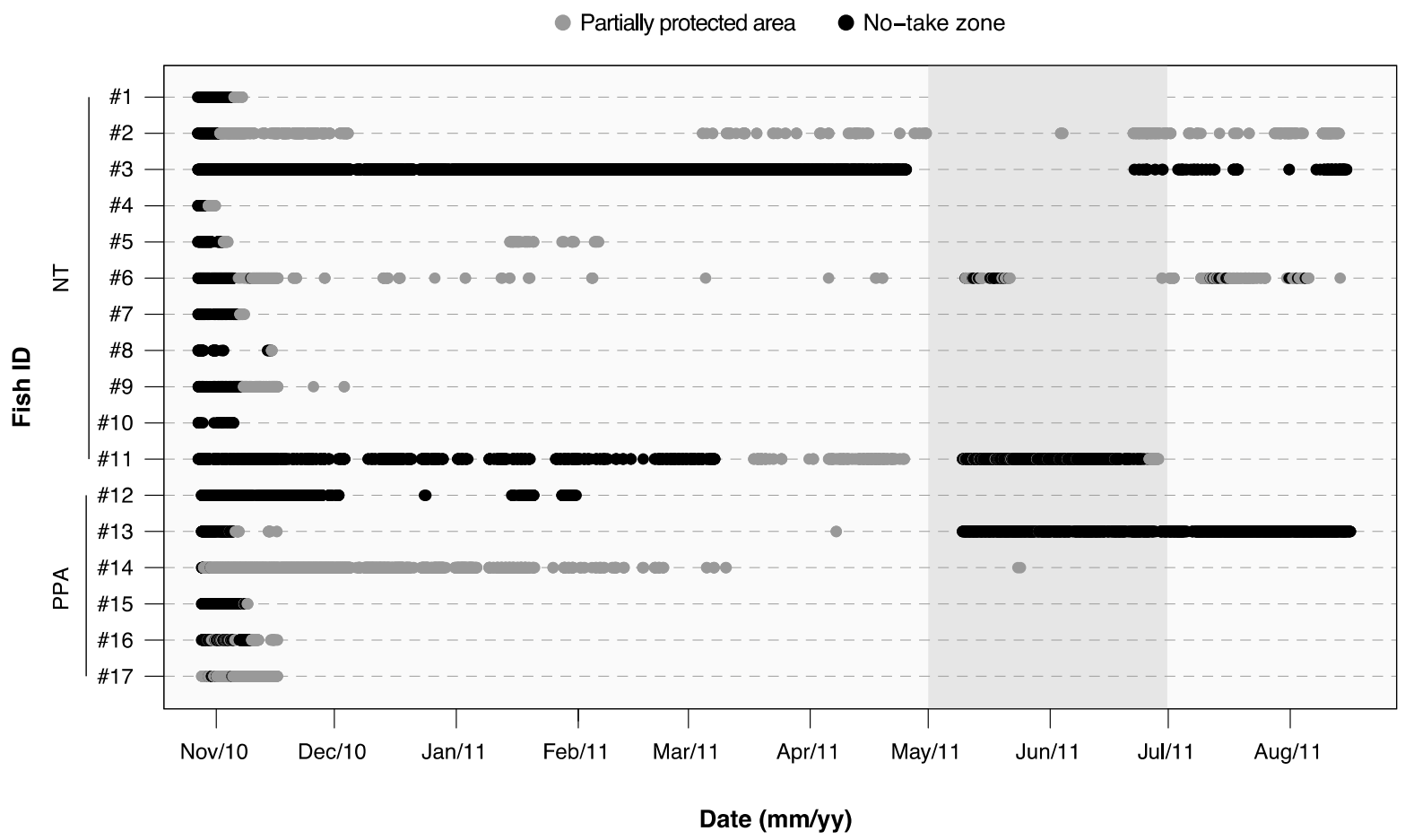

Figure 2. Detection patterns of tagged Solea senegalensis. Light grey dots correspond to detections registered within the partially protected area, while black dots correspond to detections in the no-take zone. Tagging location is indicated alongside fish IDs $(\mathrm{NT}=$ no-take; PPA= partially protected area). The shaded area (May/June) illustrates the spawning period. 
A - $\mathrm{N}^{\circ}$ of co-occurrences (60-min bins)

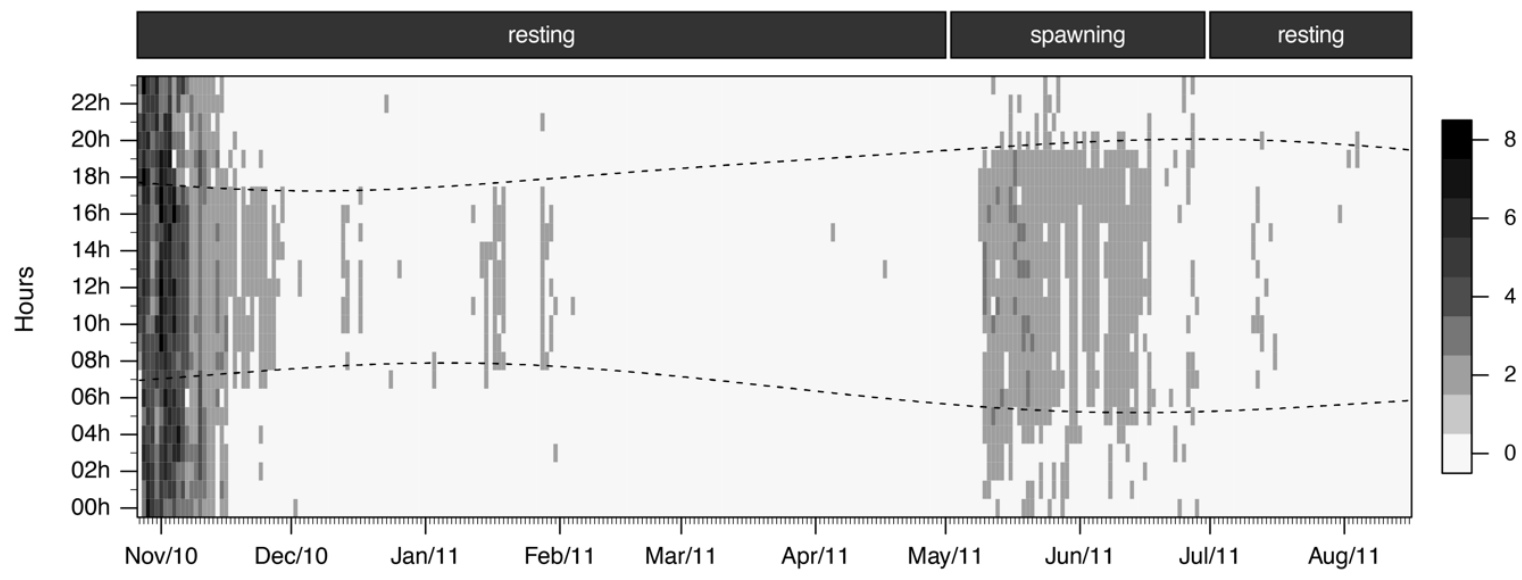

B - Sea surface temperature

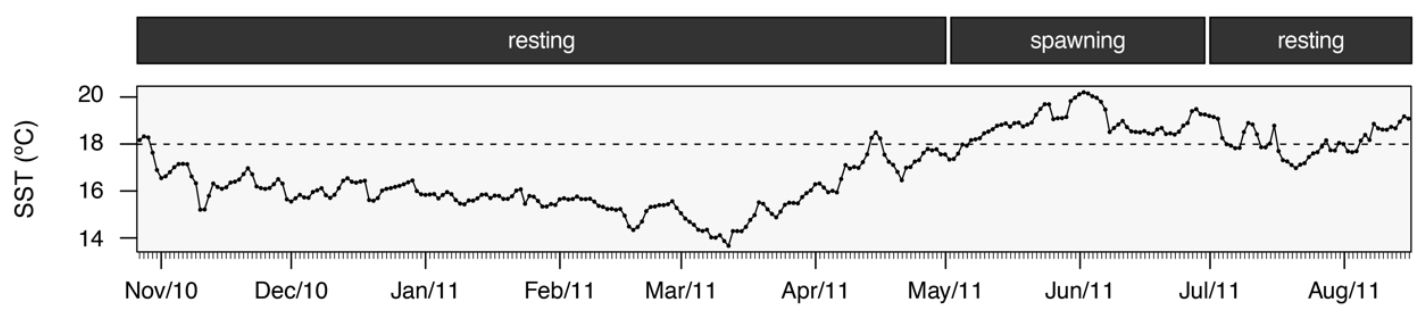

Figure 3. A - Level plot of the number of spatiotemporal co-occurrences per hour and per day. Dashed lines correspond to sunrise and sunset hours, illustrating the variation in daylight time across the study period. B - Sea surface temperature fluctuations inside the reserve throughout the study duration (obtained from the NASA Multi-scale Ultra-high Resolution Daily Climatology dataset). 

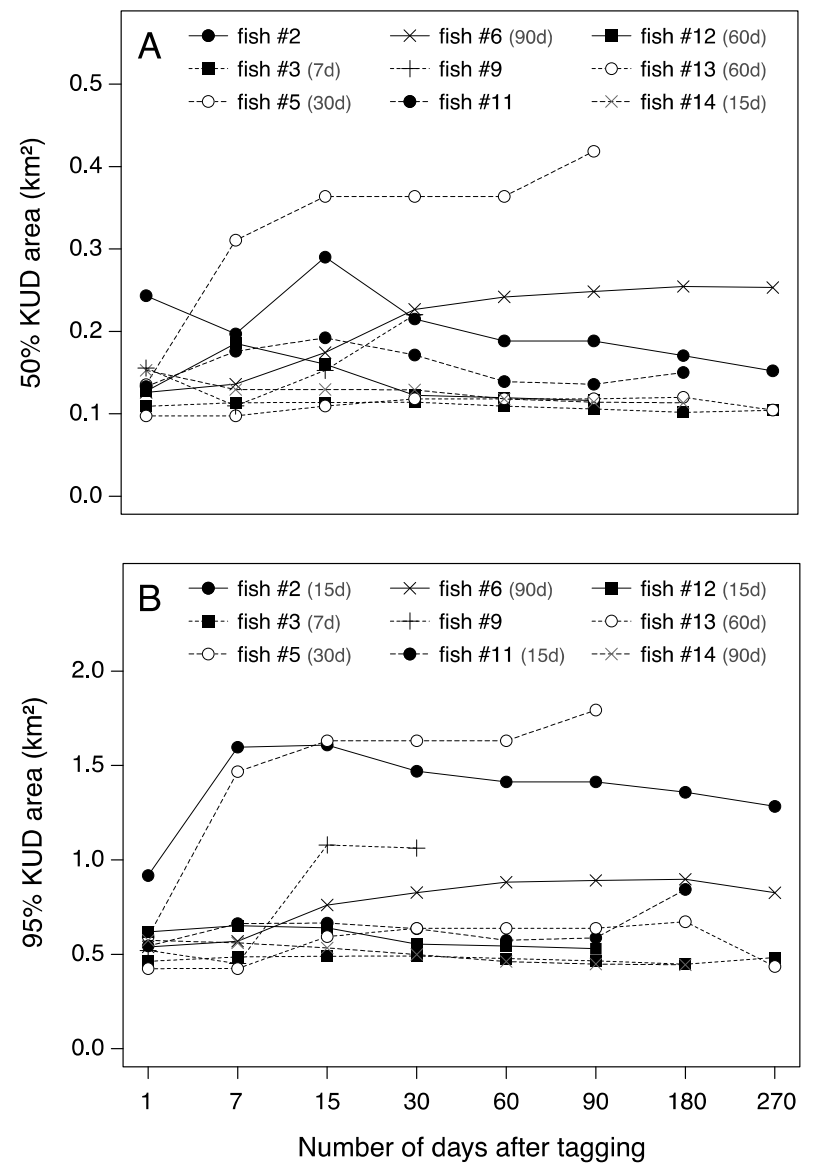

Figure 4. Cumulative core activity (A - 50\% KUD) and home range (B- 95\% KUD) areas for nine Senegalese sole whose detections spanned $>30$ days after tagging. Days required to reach an asymptote (based on a $5 \%$ change criteria) are shown next to each fish. 

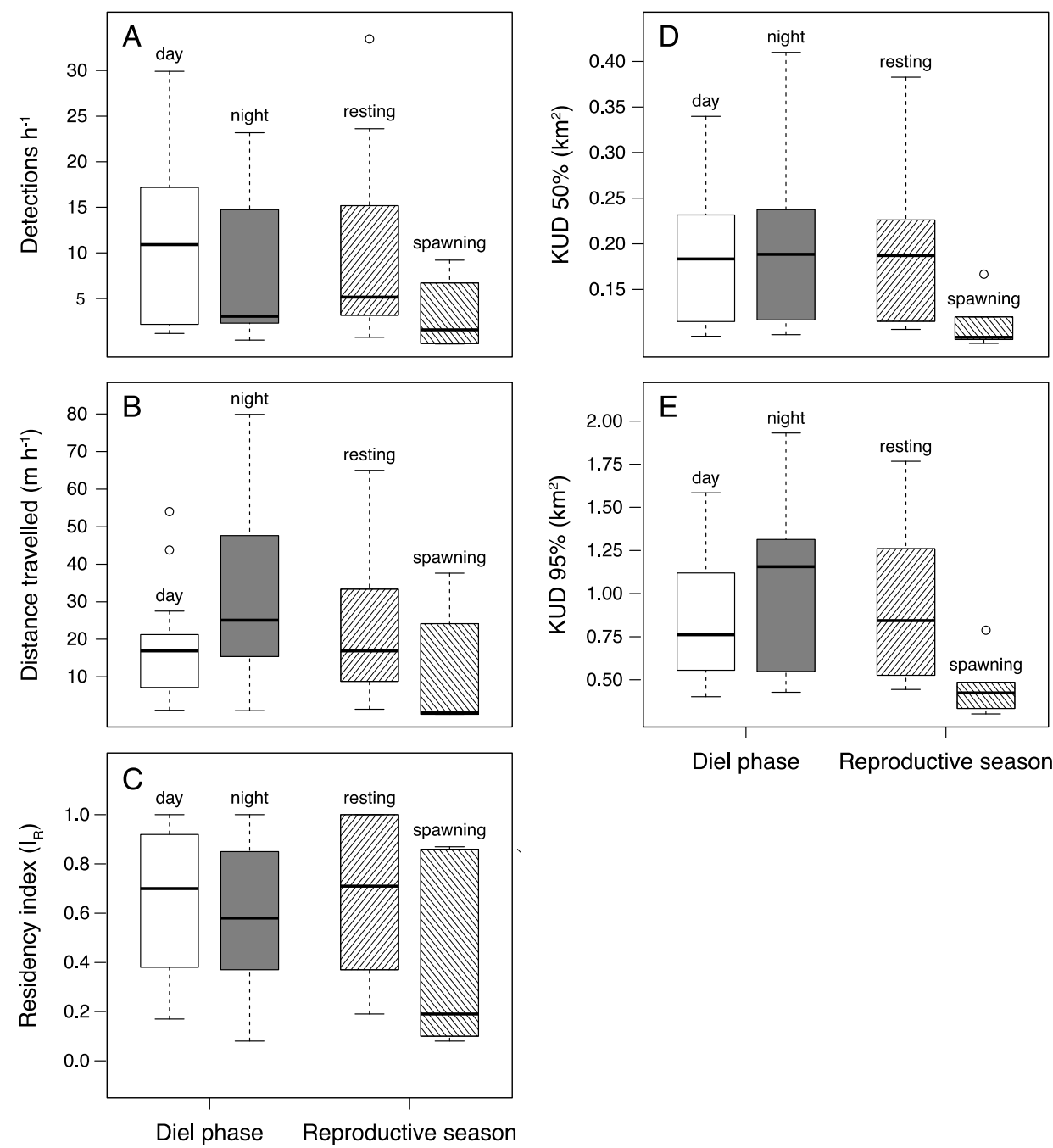

Diel phase

Reproductive season

Figure 5. Box plots of detection frequencies (detections $\left.\mathrm{h}^{-1} ; \mathrm{A}\right)$, distance travelled $\left(\mathrm{m} \mathrm{h}^{-1} ; \mathrm{B}\right)$, residency $(\mathrm{C})$, core activity areas (KUD 50\%; D) and home range areas (KUD 95\%; E) estimated across different diel phases (day vs night) and reproductive seasons (resting vs spawning). Boxes' upper and lower limits represent the 75th and 25th quartiles, horizontal lines represent medians, whiskers represent values within 1.5 interquartile ranges and dots represent outliers. 

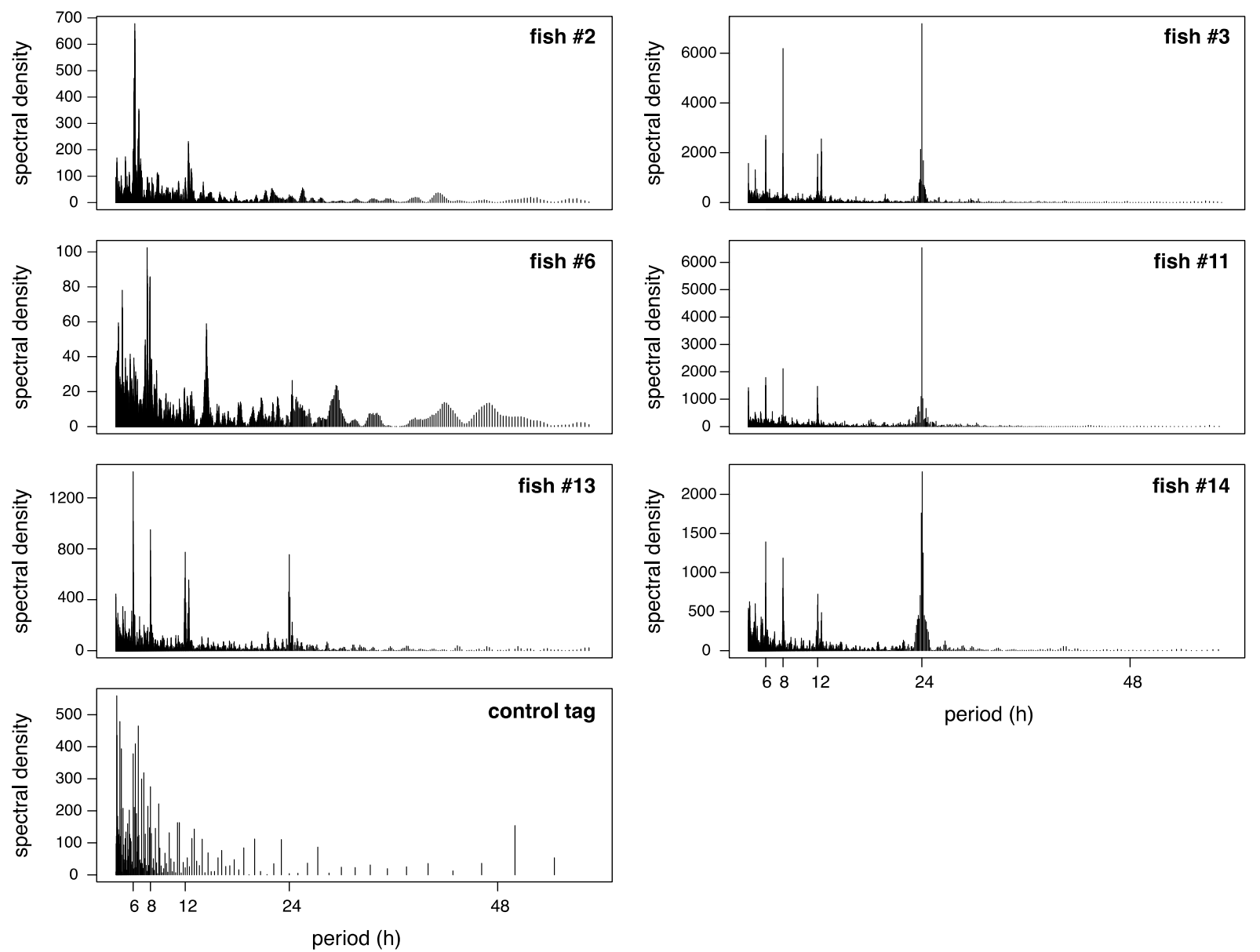

Figure 6. Fast Fourier Transform (FFT) results, depicting short-term cyclic habitat usage of fish \#2, \#3, \#6, \#11, \#13 and $\# 14$, as well as rhythmicity in detections of the control tag. Tidal cyclic patterns are associated to peaks at 6 and $12 \mathrm{~h}$ (semidiurnal tides with an average range of $\sim 2 \mathrm{~m}$ ), while diel periodicity is revealed by $24 \mathrm{~h}$ peaks. 